\begin{tabular}{|c|c|c|}
\hline$A$ & $\begin{array}{c}\text { International Journal of Current Research } \\
\text { and Academic Review }\end{array}$ & \\
\hline $\begin{array}{l}\text { EXCELLENT } \\
\text { PUBLISHERS }\end{array}$ & $\begin{array}{c}\text { ISSN: 2347-3215 (Online),;:Volume 5;,;Number } 1 \text { (January-2017) } \\
\text { Journal homepage: http://www.ijcrar.com }\end{array}$ & \\
\hline
\end{tabular}

doi: http://dx.doi.org/10.20546/ijcrar.2017.501.002

\title{
Growth Promotion and Fusarium Wilt Disease Management Ecofriendly in Chickpea by Trichoderma asperellum
}

\author{
Swapan Kumar Ghosh* and Sujoy Pal
}

Molecular Mycopathology Lab, PG Department of Botany, Ramakrishna Mission Vivekananda Centenary College, Rahara, Kolkata-700118, India

*Corresponding author

\section{Abstract}

Chickpea, Cicer arietinum L., is one of the best legumes for human consumption and widely grown in India, and other parts of the world. Fusarium wilt caused by Fusarium oxysporum ciceri, is the most important disease of chickpea throughout the world and particularly in the India. The effect of $10^{8}$ spore $/ \mathrm{ml}$ of T.asperellum gave maximum (96.00 a) percentage of seed germination. In minipot trial, there were $25 \%$ increased of percentage of germination of seeds and shoot length but $27 \%$ increase of root length and $45 \%$ increase of vigour index in compare to control. In microplot trial, $75.25 \%$ and $67.15 \%$ crop protection respectively in two consecutive years were achieved by applying $T$ asperellum. Similarly pulse yields and plant dry weight $(25.9 \& 30.12)$ were higher in compare with control and than both F.oxysporum ciceri and F.o.c.+ T. asperellum treated plots. Microplot field trials T.asperellum treated plots gave higher number of pods per plant $(47.25 ; 44.50)$ than control, F.oxysporum ciceri treated, and F.oxysporum ciceri + T.asperellum treated plots $(8.25 \& 12.25)$. T. asperellum treated plants yielded maximum functional nodules. Therefore, T.asperellum is very active growth promotion including enhancing functional root nodules and fusarial wilt management in chickpea crop. This biocontrol agent (BCA) and Plant growth promotion (PGP) agent in a dose of $10^{8}$ spore $/ \mathrm{ml}$ by seed dressing may be alternative to chemical fertilizers and fungicides in chickpea cultivation and other crops.
\end{abstract}

\section{Article Info}

Accepted: 28 December 2016

Available Online: 20 January 2017

\section{Keywords}

Biocontrol, growth promotion, T.asperellum, Chickpea, root nodule.

\section{Introduction}

Soil fertility or status of NPK (Nitrogen, Phosphate and Potassium) including micronutrient has the profound role in plant growth. Lack of soil nutrients such as NPK and plant disease continue to threaten crop production in modern agriculture and play a direct role in net loss of crop productivity in agriculture. With the advent of chemical fertilizers and pesticides /fungicides, it was thought that a permanent and reliable solution of soil fertility and crop pathogens have been achieved but it has been proved that chemical fertilizers and pesticide application are not safe to the environment as the toxicants cause environmental pollution and has harmful effects on human beings (PAN, 2007). Chemical fertilizers may have harmful effects on the soil and its life, especially when they are very concentrated and water soluble (Smith et al., 2008). Ammonium sulphate is a very strong biocide, hindering nitrogen fixation and killing nematodes and earthworms. Superphosphate has a 
negative effect on free-living nitrogen-fixing bacteria (Primavesi and Primavesi, 1990). Nitrate levels above $10 \mathrm{mg} / \mathrm{L}(10 \mathrm{ppm})$ in groundwater can cause 'blue baby syndrome' (acquired methemoglobinemia), leading to hypoxia (which can lead to coma and death if not treated) (Ward et al., 2005; Powler, 2006).Unfortunately to gain a target crop production with chemical fertilizers and pesticides, over 100 species of non target organisms are adversely affected (Alabouvette and Couteadier, 1992). Despite realization of adverse effects of chemical fertilizers and pesticides on plants, animals and environment, they are being applied indiscriminately (Eckert and Ogawa,1988; PAN, 2007) Current problems include the continued development of fungicide resistance among pathogens (Spotts and Cervantes, 1986; Holmes and Eckert, 1999; Kanetis et al., 2008; Smilanick, 2011) Recently, US Dept of Health and Human Services (2008) reported that the chemicals benomyl, carbamates and mancozeb are carcinogenic. The triazoles fungicides are causing reproductive defect of male (Goetz et al., 2007) and female mice (Rockett et al., 2006). All humans now carry a body burden of persistent pesticides, many of which are linked to chronic health effects (Schafer et al., 2004; PAN, 2007). Some pesticides are even carcinogenic and causing some human cancer such as colorectal cancer (Lee et al., 2007), breast cancer (Abdalla et al., 2003), leukemia and non-Hodgkin's lymphoma in childhood (Meinert et al., 2000). However, the potential impact on environment as well as health largely limits their application (Eckert et $a l ., 1994)$. Hence, to reduce the use or dose of chemicals, one possibility is to utilize the disease suppressing activity and plant growth promoting capacity of certain microorganisms in agrifields which should be highly ecofriendly. Such microorganisms are commonly referred to as biological control (biocontrol) agents (BCA) and plant growth promoters (PGP).and their commercial formulations are as biopesticides and biofertilizer.

The soil biology includes the rhizosphere concept (soil immediately surrounding plant roots) which was first introduced by Hiltner (1904) where microbe populations are stimulated by root activities (Mc. Cully, 2005). Trichoderma sps are active rhizosphere colonisers (Tronsmo and Harman, 1992) and act as BCA and PGP. The use of PGP/BCA offers an attractive way to replace chemical fertilizer, pesticides, and supplements; most of the isolates result in a significant increase in plant height, root length, and dry matter production of shoot and root of plants. Microorganisms such as Bacillus, Rhizobium and Pseudomonas amongst bacteria, and Aspergillus sp, Penicillium sp Trichoderma sp amongst fungi offer a biological rescue system capable of solubilizing the insoluble inorganic $\mathrm{P}$ of soil and make it available to the plants (Sharma, 2003; Chen et al., 2006). Current developments in our understanding of the functional diversity, rhizosphere colonizing ability, mode of actions and judicious application are likely to facilitate their use as reliable components in the management of sustainable agricultural systems (Zaidi et al., 2009). It has also been established that biocontrol agents enhance growth by producing growth stimulating factors (Windham et al., 1986, Ponmurugan and Baby, 2006b).

Trichoderma has a superior capacity to mobilize and take up soil nutrients compared to other organisms (Chet et al., 1997). Enhanced growth response of several plants, such as tomato(Ozbay et al., 2004; Vinale et al., 2008 ), bean (Inber et al., 1994), cucumber (Kleifield and Chet, 1992) pepper, lettuce (Vinale et al., 2008 ) were recorded by application of Trichoderma. The application of Trichoderma increased both root and shoot growth of plant. There are numerous soil microflora involved in the synthesis of auxins in pure culture and soil. Some of the P-solubilizing bacteria and fungi act as plant growth promoters due to their ability to produce IAA (Souchie $e t$ al., 2007). Biological Control of pathogens by microorganisms has been considered a more natural and environmentally acceptable alternative to the existing chemical treatment methods and also found that many isolates of Trichoderma spp. by producing non-volatile metabolites, volatile metabolites, enzymes which were active against a range of pathogenic fungi (Chet et al., 2009; Barakat et al., 2006; Karthikeyan et al., 2006; Eziashi et al., 2007; Mukhopadhyay, 2009). T. harzianum colonizes $S$. rolfsii hyphae, disrupts mycelial growth and kills this pathogen. Trichoderma are used as biopesticide, biofertilizer or fertility promoter (Harman et al., 2004; Harmen, 2006; Vinale et al., 2008). Chickpea, Cicer arietinum L., is one of the best legumes for human consumption and widely grown in India, Northern Sudan and other parts of the world. It is the world's fourth most important pulse crop after soybeans (Glycine max L.), beans (Phaseolus vulgaris L.) and peas (Psium sativum L.) (FAO, 2012). In India, chickpea is ranked first in terms of production and consumption in the world. About $65 \%$ of global area with $68 \%$ of global production of chickpea is contributed by India (Amarender and Devraj, 2010). Fusarium wilt caused by Fusarium oxysporum Schlechtend Fr. f. sp. ciceri (Padwick) Erwin. Matuo and Sato, is the most important soil-borne disease of chickpea throughout the world and 
particularly in the Indian Subcontinent, the Mediterranean Basin and California (Nene and Reddy, 1987; Dubey et al., 2007). The International strategies include minimum use of chemicals for checking the pathogen, pollution, encouragement of beneficial biological agents to reduce pathogen inoculums (Bendre and Barhate, 1998; Harman and Kubicek, 1998). The main objectives of this work are to apply one strain of Trichoderma asperellum in chickpea field for growth promotion and Fusarium wilt management ecofriendly without applying chemical fertilizers and fungicides for clean environment.

\section{Material and Methods}

\section{Isolation and purification of fungal antagonist}

Fungus was isolated from agrisoil; by dilution plate technique in PDA and Rose Bengal Agar medium supplemented with antibiotic at $28 \pm 2{ }^{\circ} \mathrm{C}$ temperature. Purification was done by single hyphal tip method (Dhingra and Sinclair, 1986).

\section{Phenotypical Identification of fungal antagonist}

The fungal isolate was phenotypically identified with cultural characteristics like culture growth rate, colony texture, margin, color, exude, reverse plate characters etc. and microscopical (morphological) characterstics i.e. spore length and breadth, spore type, spore septum, hyphal type, septum formation. The collected data comparing with fungal published key (Domsch et al., 1980) revealed the identity of the fungus.

\section{Molecular Identification of fungal antagonist by PCR method}

\section{Genomic DNA extraction}

Genomic DNA of fungus was extracted by modified CTAB method (Chutima et al., 2010). and purified by fungal DNA Purification Kit (HiMedia Laboratories Pvt. Ltd.). The concentration of DNA was checked by electrophoresis in $1 \%$ agarose gel stained with ethidium bromide under UV light.

\section{PCR of ITS1-5.8S- ITS-2 of r DNA}

Genomic DNA from fungus was extracted and the internal transcribed spacer (ITS1-5.8S-ITS2) regions were amplified by PCR technology using with DNA amplification reagent kit manual (GeNei) along with fungus specific forward primer ITS-1 $\mathrm{F}$ (CTTGGTCATTTAGAGGAA-GTAA) (Gardes and Bruns,1993) and the reverse primer ITS-4 (TCCTCCGCTTATTGATA-TGC) (White et al., 1990). PCR was carried out using the following protocol, modified from Gardes and Bruns (1993); initial denaturation at $95^{\circ} \mathrm{C}$ for $85 \mathrm{~s}$, followed by 37 cycles of denaturation at $95^{\circ} \mathrm{C}$ for $30 \mathrm{~s}$, annealing at $55^{\circ} \mathrm{C}$ for $50 \mathrm{~s}$, extension at $72^{\circ} \mathrm{C}$ for $10 \mathrm{~min}$. The reaction was held at $4^{\circ} \mathrm{C}$. Amplicon was electrophoresed in a $1 \%$ Agarose gel stained with ethidium bromide and visualized under UV. Concentration of the amplicon was checked in UV-Vis Spectrophotometer, the ratio of absorbance at $260 \mathrm{~nm}$ and $280 \mathrm{~nm}$ is used to assess the purity of DNA. A ratio of $\sim 1.8$ is generally accepted as "pure" for DNA. The amplicon was purified using Gene JET gel Extraction Kit (Thermo Scientific).

\section{Gene Sequencing}

Sequencing of PCR product was carried out in Sci Genome Labs Pvt Ltd, Kerala, India and the sequence obtained was submitted to NCBI Gene Bank. The sequence analysis was carried out using bio-informatics tool BLAST of NCBI.

Gram plant protection and plant seedling growth promoting experiments

\section{Preparation of spore suspension of T.asperellum antagonists}

Trichoderma asperellum was subcultured in slants of PDA for ten days. After ten days, cotton plugs of culture tubes were unplugged and $10 \mathrm{ml}$ of sterilized distilled water was filled inside. Then cotton plug again fitted. The culture tubes were jerked for 15 minutes for dislodging the spores in water. Then water with spores was taken out in beaker. The number of spore/ml was measured by haemocytometer. The spore suspension was made as per requisition by adding sterile water.

\section{Preparation of inoculum of $F$. oxysporum ciceri for field trial}

Pure culture of the wilt fungus $F$. oxysporum ciceri was cultured in laboratory. The fungus was mass cultured on broken maize seeds. The seeds were soaked overnight in a 5\% sucrose and $30 \mathrm{mg} / \mathrm{L}$ chloramphenicol solution. The soaked seeds were transferred to $500 \mathrm{ml}$ conical flasks and autoclaved twice at $15 \mathrm{~kg} \mathrm{~cm}^{2}, 121^{\circ} \mathrm{C}$, for 20 minutes. Thereafter, the flasks were inoculated with pure 
culture of $F$. oxysporum ciceri and incubated at $28 \pm 2^{\circ} \mathrm{C}$ for 10 days in an incubator. For soil inoculation, fungus colonised seeds $(500 \mathrm{~g})$ were ground in a mixer-grinder and asuspended in $10 \mathrm{ml}$ tap water. The suspension $(10: 1)$ was spread uniformly on a microplot of $3 \times 2 \mathrm{~m}$ to achieve an inoculums level of $1.5 \mathrm{~g}$ colonised seeds kg ${ }^{-1}$ soil. Soil inoculation was done two days before seed was sown. Pots were arranged in randomized design. After sowing the treated or untreated seeds, minipots were observed every day for pre- emergence and postemergence wilts of seedlings. The number of preemergence and post-emergence wilted seedlings or non wilted seedlings was recorded. The data were statistically analysed.

\section{Effect of $T$. asperellum on seed germination, root length \& shoot length of chickpea}

i) Petri plate culture: A suspension of spore $\left(10^{8} / \mathrm{ml}\right)$ fungal was made in sterile distilled water. $10 \mathrm{gms}$ of fresh \& disease free seeds of chickpea c.v. B-110 were dipped in $100 \mathrm{ml}$ suspension of spore of antagonist for overnight, then they were placed in the wetted blotting papers placed in petri dishes. In each petri dish 20 seeds were taken. Five sets were prepared. The sets were placed in room temperature. Control or untreated sets were also arranged. Seedling raised from seeds treated with T.asperellum recorded and vigour index values based on germination and seedling length were also calculated statistically by the following formula (AbdulBaki and Anderson, 1973)

Vigour index $=[$ Mean Root length + Mean Shoot length] x Percentage of Seed germination

ii) In minipot culture: Twenty minipot (plastic tea cup) were filled with fertile soil. A suspension of spore $\left(10^{8} /\right.$ $\mathrm{ml}$ ) fungal antagonist was made in sterile distilled water. Ten gms of fresh \& disease free chickpea seeds were dipped in $100 \mathrm{ml}$ suspension of spore of antagonists for overnight, then they were sown in minipot. In each pot one seed was sown. One control set (10 minipot each with one seedling) where seeds were soaked in sterile water over night was arranged. After 15 days the treated $\&$ non-treated seedling of chickpea were uprooted and the soils adherence on roots were washed. The water of washed seedling was blotted by blotting paper. The root length, \& shoot length were measured by $\mathrm{mm}$ scale. The number of root branches of both treated and control (untreated) was recorded. The data collected were statistically ( $\mathrm{t}$-test) analysed.
Effect of T.asperellum on chickpea protection from wilt disease

Hundred minipot (plastic tea cup) were filled with fertile soil. A suspension of spore $\left(10^{8}\right.$ spores/ $\left.\mathrm{ml}\right) T$. asperellum was made in sterile distilled water. $100 \mathrm{gms}$ of fresh \& disease free chickpea seeds were dipped in $100 \mathrm{ml}$ suspension of spore of the antagonist for overnight, then they were sown in minipot. In each minipot $5 \mathrm{ml}$ of spore suspension $\left(10^{8}\right.$ spores/ $\left.\mathrm{ml}\right)$ of $F$. oxysporum ciceri and $5 \mathrm{ml}$ of spore suspension $\left(10^{8}\right.$ spores/ $\left.\mathrm{ml}\right)$ of fungal antagonist. One seed was sown in each minipot. Similarly a suspension of spores $\left(10^{8}\right.$ spores/ $\left.\mathrm{ml}\right)$ of $F$. oxysporum ciceri was made in sterile distilled water. $100 \mathrm{gms}$ of fresh $\&$ disease free chickpea seeds were dipped in $100 \mathrm{ml}$ suspension of spores for overnight, then they were sown in minipot and then only $5 \mathrm{ml}$ of spore suspension of $F$. oxysporum ciceri was mixed in these miniport .One control set (10 minipot each with one seedling) where seeds were soaked in sterile water over night was arranged. For each treatment 10 minipots were taken. All treated or control (untreated set) was run. The number of germinated and non-germinated seeds was recorded and percent of seed germination was calculated. The length of shoot and root of germinated seeds were measured by $\mathrm{mm}$ scale or $\mathrm{mm}$ graph paper by $24 \mathrm{hr}$. intervals up to 15 days.

\section{Effect of T.asperellum on protection of chickpea from wilt and growth promotion in mini plot field trial}

A field of $25 \times 15 \mathrm{~m}$ was prepared in which 30 microplots $(3 \times 2 \mathrm{~m})$ were demarcated by $25 \mathrm{~cm}$ wide, raised margins. Each treatment was applied on three micro- plots, distributed in a completely randomized block design in the field. A suspension of spore $\left(10^{8}\right.$ spores/ ml $)$ T.asperellum was made in sterile distilled water. 100gms of fresh \& disease free chickpea seeds were dipped in $100 \mathrm{ml}$ suspension of spore of $T$. asperellum for overnight, then they were sown in three rows (57 seeds /row) in the micro -plots, irrespective of whether the wilt fungus was added into the soil. The field was irrigated a week after sowing. At maturity, four months after sowing, twenty -five plants from each microplot were uprooted to determine dry matter production and grain yield. Two month old plants were randomly uprooted from each microplot (10 plants / micro-plot) to count the root nodules. Pink and healthy nodules were counted as functional nodules, dark-brown and degenerated ones as non-functional nodules. Wilt incidence $(\%)$ and wilt severity were recorded on two and a half month old plants. Wilt severity (\%) was 
scored on a $0-5$ scale: $0=$ no wilt $1=1-20 \%: 2=21-40 \%$ $; 3=1-60 \% ; 4=61-80 \% ; 5=81-100 \%$

The rhizosphere population of the wilt fungus and the bio-agents was estimated monthly from December to
April using the dilution plate method. The Fusarium oxysporum $f$. sp. ciceri was identified on the basis of colony and conidial characteristics (Jalali and Chand, 1992). Wilt incidence and severity were expressed according to the following formulae:

$$
\begin{gathered}
\text { Wilt incidence }(\%)=\frac{\text { No. of wilted plants in a microplot }}{\text { Total No. of plants in a microplot }} \times 100 \\
\text { Wilt severity }(\%)=\frac{\text { Wilted branches in a plant }}{\text { Total No.of branches in a plant }} \times 100
\end{gathered}
$$

The experiment was conducted for two successive growing seasons (20012-2013 \& 2013-2014) under identical conditions. Observations from the twenty-five plants of each microplot were averaged and considered one replicate.

Since three microplots were used for each treatment, there were therefore three replicates. Data on plant growth and yields were recorded. Wilt incidence was angularly transformed before analysis. Least significance difference (LSD) was calculated at $\mathrm{P}=0.05$ for all variables to compare individual treatments.

\section{Results and Discussion}

\section{Phenotypical Identification of Fungi}

Phenotypically the fungus was identified as Trichederma asperellum.

\section{Molecular identification by ITS 1-5.8S-ITS 2 of $18 S \mathrm{r}$ DNA}

BLAST analysis was done with help of NCBI nucleotide sequence analysis; data analysis of nucleotide sequence (632 bp) of isolated fungi was showed 100\% homology with published sequence of Trichoderma asperellum. The sequence was submitted in NCBI Bankit and published with the Gene Bank accession number KM604669.1

\section{Effect of $T$. asperellum on seed germination of Chickpea in Petri dishes}

The effect of concentration of spore Trichoderma asperellum on seed germination of chickpea indicated that $10^{8} \mathrm{spore} / \mathrm{ml}$ of Trichoderma asperellum gave maximum (96.00 a) percentage of seed germination followed by $10^{7}, 10^{6}, 10^{5}$ spores $/ \mathrm{ml}$ (Table 1 ). Seedling raised from seeds treated with T.asperellum recorded significantly higher vigour index (2158.30) values based on germination and seedling length which were more than control (1454.17) (Table 4). The above result agreed with the finding of Krishanmoorthy (1987) and he reported increase germination \& seedling vigour of tomato and chilli respectively by Trichoderma. Moreover, some workers (Benitez et al., 1998; Kumar and Dubey, 2001) also reported beneficial effect of Trichodermas on seed germination.

Effect of Trichoderma asperellum on growth promotion of Chickpea in mini pot trial

In mature disease free seeds (10) of chickpea were dipped in spore suspension $\left(10^{8}\right.$ spore $\left./ \mathrm{ml}\right)$ for $24 \mathrm{hrs}$ and sown in minipots in randomized block design. 10 seeds were dipped in sterile distilled water and sown in 10 minipots and it was treated as control. After 15 days shoot length, root length and branches of roots of 10 treated plants were $17.9 \mathrm{~cm}, 4.7 \mathrm{~cm}$ and $10.9 \mathrm{~cm}$ respectively while in control they were $13.3 \mathrm{~cm}, 7.4 \mathrm{~cm}$ and $3.8 \mathrm{~cm}$ respectively (Table 2). After data were statistically analysed (t-test), it was interesting to note that T.asperellum increases significant length of shoot and number of root branch of chickpea. But effect of T.asperellum on the length of main roots was not statistically significant at 5\% and $1 \%$ level. On the other hand, the calculated $t$ value of root length (1.746) is smaller than tabulated value (2.262) at 0.05 levels and tabulated value (3.250) at 0.01 levels at $9 \mathrm{df}$. So Null hypothesis is accepted. Therefore, it can be calculated that main root length of chickpea treated with T.asperellum is not significantly different from main root length of chickpea (control untreated).

Calculated $t$ value of shoot length (6.73) and root branches (5.428) are greater than tabulated $t$ value (2.262) at $\mathrm{P}=0.05$ level and also than tabulated $t$ value (3.250) at $\mathrm{P}=0.01$ level at $9 \mathrm{df}$. Thus the null hypothesis is rejected. It can be concluded that Shoot length and 
root branch of Chickpea of T. asperellum treated plants are statistically significantly different from control (untreated).There was $25 \%$ increased of percentage of germination of seeds and shoot length but $27 \%$ increase of root length and $45 \%$ increase of vigour index of $T$. asperellum treated Chickpea in compare to control (Table 2).There was a reduction in the morphological characters of the Sorghum in control but Trichoderma treatments, there was $40 \%$ increased shoot, root length, fresh weight dry weight and vigour index of the plant, when compared to control. The reason for the increase in growth parameters and vigour index may be certain plant growth hormones and secondary metabolites produced by $P$. fluorescens and $T$. harzianum which are known to have increased growth rate as reported by Lynch and Hobbie (1991) and Kimura et al. (1992).

\section{The study of protection of chickpea from wilt disease by applying $T$. asperellum in minipot trial}

Spore suspension of $T$. asperellum was prepared and diluted according to requirement; seeds of chickpea were dipped over night before sowing. In pot trial the study of protection of wilt disease by $T$. asperellum was conducted. The results (Figure 2) revealed that minipots treated with $F$. oxysporum ciceri caused $95 \%$ wilt of Chickpea but when both $F$. oxysporum ciceri and $T$. asperellum were treated in the pots, T. asperellum checked $70 \%$ of wilt of Chickpea. It suggested that without using any fungicides, Chickpea can be protected from wilt by seed treatment with $T$. asperellum $\left(10^{5} / \mathrm{spore} / \mathrm{ml}\right)$. As it was minipot trials, field trial may proved its actual potentiality.

The study of protection of chickpea from wilt disease and Plant growth promotion (Number of pods/plant, Yield/plant, Plant dry weight and functional nodules)in two years ( 2012-13 \& 2013-14 ) mini plot field trials by applying $T$.asperellum

The study of protection of chickpea from wilt disease by applying $T$. asperellum in microplot field trial was conducted for two years (2012-13, 2013-14). It revealed that $75.25 \%$ and $67.15 \%$ crop protection respectively in two consecutive years were achieved by applying $T$. asperellum in seed treatment (Fig 3). There was a significant decline in the yield of chickpea infected by $F$. oxysporum ciceri (Jalali and Chand, 1992). Moreover for plant growth promotion (Number of pods/plant, Yield/plant, Plant dry weight and functional nodules) two years (2012-13 \& 2013-14) microplot field trials (Table 4) showed that in both year T. asperellum treated plots gave higher number of pods per plant ( 47.25 ; 44.50 ) than control, F. oxysporum ciceri treated, and F.oxysporum ciceri $+T$. asperellum treated plots $(8.25 \&$ 12.25 ). Similarly pulse yields and plant dry weight (25.9 and 30.12) were higher in compare with control, and then both F. oxysporum ciceri and F.o.c. $+T$. asperellum treated plots. The two month- old plants were randomly uprooted from each microplot (10 plants/ microplot) to count functional and non-functional nodule. It revealed that $T$. asperellum treated plants yielded maximum functional nodules. The number of functional nodules increased by $33 \%$ with $T$. harzianum (Khan et al., 2004). That there is a significant decline in the yield of chickpea infected with $F$. oxysporum f. sp. ciceri has already been reported in India (Jalali and Chand, 1992). Infection with $F$. oxysporum $\mathrm{f}$. sp. ciceri suppressed the rhizobial nodules on the roots of chickpea plants. The bioagents significantly increased the number of functional nodules. Rhizobacteria (Pseudomonas spp.) and mycoparasites (Trichoderma spp.) are known to synergise Bradyrhizobium spp. (Khan et al., 2004). .Effectiveness of $T$. viride, $T$. harzianium and $T$. (Gliocladium) virens against chickpea wilt complex has also been reported by Sonawane and Pawar (2001), Tewari and Mukhopadhyay (2001) and Gupta et al. (2003).Application of Trichoderma as BCA can bring substantial changes in plant metabolism to promote plant growth, increase nutrient availability, improve crop production and enhance disease resistance (Harman et al., 2004).

In chickpea, T. harzianum, enhanced the top length, pod numbers, total dry biomass and yield than control ( Rai and Singh, 2004). Biological control of F. oxysporum ciceri by non pathogenic Fusarium was recorded by Kaur et al., (2003) Similarly, the results of this field trial were corroborated with the findings of former workers (Khan et al., 2004). The pool data of results indicated that $T$. asperellum treated plants gave $21.12 \%$ better yield of number of pod, $40 \%$ better pulse yield, $35.51 \%$ of better yield of functional nodules in compare to F.oxysporum ciceri treated and $11.33 \%$ of increase of number of Pod, $18.43 \%$ of pulse yield, 15.83 of plant dry weight and $17.58 \%$ of functional nodules in compare of control (untreated). Certain isolates of Trichoderma, from the rhizosphere of some cultivated crops, displayed the activity of plant growth promotion as well as disease suppression (Hyakumachi, 1994; Chang et al., 1986).

The mean values of top length, total dry biomass of rice showed significant increase when treated with $T$. harzianum in comparison to control (Rai and Singh, 
2004). Andrabi et al. (2010) conducted experiments for controlling wilt disease of chickpea by various strategies and recorded that seed coating with $T$. asperellum resulted in minimum disease incidence (9.24\%). The primary mechanisms of disease suppression by BCA are production of antimicrobial secondary metabolites such as siderophore (Neilands, 1981), antibiotics (Keel et al., 1992), volatile substances (eg $\mathrm{HCN}, \mathrm{NH}_{3}$ ) (Wei et al., 1991; Ghosh et al., 2014), plant hormones (Sharaf and Farrage, 2004), and other mechanisms. Trichoderma utilizes mycoparasitism to mitigate phytopathogenesis (Harman and Kubicek, 1998; Pan and Ghosh, 1997) and antibiosis (Sivasithamparam and Ghisalberti, 1998). The efficacy of Trichoderma as BCA is believed to involve antibiotic production( eg. gliotoxin, viridin), ethyl acetate
(Claydown et al., 1987) and some cell wall degrading enzymes (Larito et al., 1976; Bello et al., 1997,Vinale et al., 2009; Howell, 2003).

Trichoderma species produces growth factors which increase the rate of seed germination (Benitez et al., 1998; Kumar and Dubey, 2001). Some studies reported that the reduction in disease incidence and increase in seed germination lead to higher yield in Trichoderma treated seeds and soil (Podder et al., 2004). Srivastava (2004) reported that root colonization by Trichoderma strains frequently enhances root growth and development. The strains of Trichoderma increased root development in several crops, under both green-house or field conditions (Harman et al., 2004).

Table.1 Effect of concentration of spore of T .asperellum on seed germination of Chickpea

\begin{tabular}{|c|c|}
\hline $\begin{array}{c}\text { Concentration of spore of } \\
T . \text { asperellum }\end{array}$ & $\begin{array}{c}\text { Percentage of seed } \\
\text { germination }\end{array}$ \\
\hline $10^{4}$ & $77.25 \mathrm{c}(61.55)$ \\
\hline $10^{5}$ & $80.75 \mathrm{c}(64.01)$ \\
\hline $10^{6}$ & $90.00 \mathrm{~b}(71.56)$ \\
\hline $10^{7}$ & $95.50 \mathrm{a}(77.75)$ \\
\hline $10^{8}$ & $96.00 \mathrm{a}(78.46)$ \\
\hline Control & $70.25 \mathrm{~d}(56.98)$ \\
\hline
\end{tabular}

Note: Mean values followed by a different letter indicated significant different $(P=0.05)$, according to Duncan's multiple range test. (Data in the parentheses are angular trnsformed value of percentage)

Table.2 Effect of T.asperellum on growth promotion of Chickpea in mini pot trial

\begin{tabular}{|c|c|c|c|c|c|c|}
\hline \multirow{2}{*}{ Plant No. } & \multicolumn{2}{|c|}{ Shoot length $(\mathrm{cm})$} & \multicolumn{2}{|c|}{ Root length $(\mathrm{cm})$} & \multicolumn{2}{|c|}{ Root branch $(\mathrm{cm})$} \\
\hline & Treated & Control & Treated & Control & Treated & Control \\
\hline 1. & 18 & 15 & 02 & 11 & 04 & 03 \\
\hline 2. & 20 & 12 & 03 & 04 & 16 & 04 \\
\hline 3. & 19 & 14 & 07 & 09 & 08 & 03 \\
\hline 4. & 18 & 11 & 05 & 04 & 12 & Nil \\
\hline 5. & 16 & 13 & 05 & 10 & 12 & 04 \\
\hline 6. & 20 & 13 & 07 & 04 & 16 & 04 \\
\hline 7. & 18 & 13 & 05 & 05 & 12 & 05 \\
\hline 8. & 16 & 15 & 05 & 06 & 08 & 04 \\
\hline 9. & 17 & 12 & 02 & 05 & 09 & 05 \\
\hline 10 & 17 & 15 & 06 & 16 & 12 & 06 \\
\hline Mean & 17.9 & 13.3 & 4.7 & 7.4 & 10.9 & 3.8 \\
\hline
\end{tabular}


Table.3 Calculated t- value, tabulated t- value of shoot, root length and root branches

\begin{tabular}{|c|c|c|c|}
\hline & Shoot length & Root length & $\begin{array}{c}\text { Root } \\
\text { branches }\end{array}$ \\
\hline Calculated t value & 6.73 & 1.746 & 5.428 \\
\hline $\begin{array}{l}\text { Tabulated } \mathrm{t} \text { value } \\
\qquad(\mathrm{P}=0.05)\end{array}$ & 2.262 & 2.262 & 2.262 \\
\hline $\begin{array}{c}\text { Tabulated t } \\
\text { value }(\mathrm{P}=0.01)\end{array}$ & 3.250 & 3.250 & 3.250 \\
\hline
\end{tabular}

Table.4 Effect of T. asperellum on shoot length, root length, vigour index of Chickpea

\begin{tabular}{|c|c|c|c|c|c|}
\hline Sl no. & Treatment & $\begin{array}{c}\text { Percentage of seed } \\
\text { germination }(\%)\end{array}$ & $\begin{array}{c}\text { Shoot length } \\
(\mathrm{cm})\end{array}$ & $\begin{array}{c}\text { Root length } \\
(\mathrm{cm})\end{array}$ & $\begin{array}{c}\text { Vigour Index } \\
(\mathrm{VI})\end{array}$ \\
\hline 1. & T. asperellum & 95.50 & 17.9 & 4.7 & 2158.30 \\
\hline 2. & Control & 70.25 & 13.3 & 7.4 & 1454.17 \\
\hline
\end{tabular}

Table.5 Effect of seed treatment on dry matter, yield, nodulation, wilt incidence and severity of chickpea plants inoculated with Fusarium oxysporum f. sp. ciceri

\begin{tabular}{|c|c|c|c|c|c|c|c|c|c|c|c|c|c|c|c|}
\hline \multirow{3}{*}{ Treatment } & \multicolumn{3}{|c|}{ No. of pods per plant } & \multicolumn{3}{|c|}{$\begin{array}{l}\text { Yield plant } \\
\text { ( per g ) }\end{array}$} & \multicolumn{3}{|c|}{ Plant dry weight (g) } & \multicolumn{6}{|c|}{ Nodules/root system } \\
\hline & \multirow{2}{*}{$\begin{array}{c}2012 \\
-13\end{array}$} & \multirow{2}{*}{$\begin{array}{c}2013- \\
14\end{array}$} & \multirow{2}{*}{ Pool } & \multirow{2}{*}{$\begin{array}{c}2012 \\
-13\end{array}$} & \multirow{2}{*}{$\begin{array}{c}2013 \\
-14\end{array}$} & \multirow[b]{2}{*}{ pool } & \multirow{2}{*}{$\begin{array}{c}2012- \\
13\end{array}$} & \multirow{2}{*}{$\begin{array}{c}2013 \\
-14\end{array}$} & \multirow[b]{2}{*}{ Pool } & \multicolumn{3}{|c|}{ Functional } & \multicolumn{3}{|c|}{ Non-functional } \\
\hline & & & & & & & & & & $\begin{array}{c}2012- \\
13\end{array}$ & $\begin{array}{c}2013 \\
-14 \\
\end{array}$ & Pool & $\begin{array}{c}2012- \\
13\end{array}$ & $\begin{array}{c}2013- \\
14\end{array}$ & Pool \\
\hline Control & 39.10 & 42.25 & 81.35 & 7.22 & 9.50 & 16.72 & 21.9 & 25.25 & 47.15 & 35.00 & 14.20 & 49.20 & 39.00 & 12.20 & 51.20 \\
\hline $\begin{array}{c}\text { F.oxysporum } \\
\text { ciceri }\end{array}$ & 32.00 & 40.37 & 72.37 & 5.05 & 7.25 & 12.30 & 17.5 & 19.50 & 37.00 & 26.0 & 12.50 & 38.50 & 32.00 & 10.20 & 42.20 \\
\hline T. asperellum & 44.50 & 47.25 & 91.75 & 8.25 & 12.25 & 20.50 & 25.9 & 30.12 & 56.02 & 46.7 & 13.00 & 59.70 & 50.25 & 14.00 & 64.25 \\
\hline $\begin{array}{c}\text { F.oxysporum } \\
\text { ciceri }+T . \\
\text { asperellum }\end{array}$ & 35.00 & 42.25 & 77.25 & 6.50 & 8.15 & 14.65 & 23.2 & 26.50 & 49.70 & 32.05 & 13.8 & 46.05 & 36.00 & 14.20 & 50.20 \\
\hline $\begin{array}{c}\mathrm{SEm} \pm \\
\mathrm{CD} \\
(\mathrm{P} \leq 0.05)\end{array}$ & $\begin{array}{l}1.893 \\
\pm \\
2.341\end{array}$ & $\begin{array}{c}0.987 \pm \\
1.987\end{array}$ & & $\begin{array}{c}0.012 \\
3 \pm \\
1.895\end{array}$ & $\begin{array}{l}0.123 \\
\pm \\
1.564\end{array}$ & & $\begin{array}{c}1.987 \pm \\
3.123\end{array}$ & $\begin{array}{l}2.023 \\
\pm \\
3.786\end{array}$ & & $\begin{array}{c}2.675 \pm \\
3.563\end{array}$ & $\begin{array}{c}1.023 \\
\pm \\
2.060\end{array}$ & & $\begin{array}{c}1.993 \pm \\
2.451\end{array}$ & $\begin{array}{c}2.785 \pm \\
4.312\end{array}$ & \\
\hline
\end{tabular}

Fig.1 Effect of Trichoderma asperellum on growth promotion of Chickpea in mini pot trial (A) \& measurement of the plants (B)

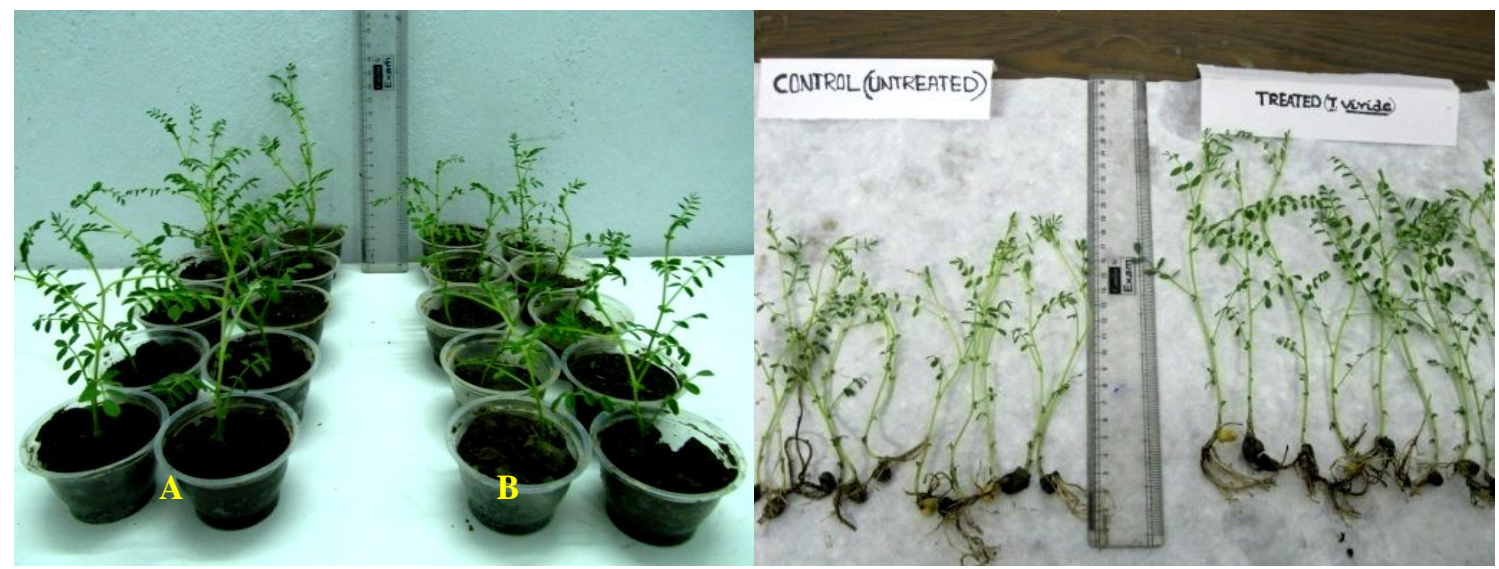


Fig.2 Percentage of pre- emergence and post emergence of wilt of chickpea with F. oxysporum ciceri, F.oxysporum ciceri+ T. asperellum and control(untreated)

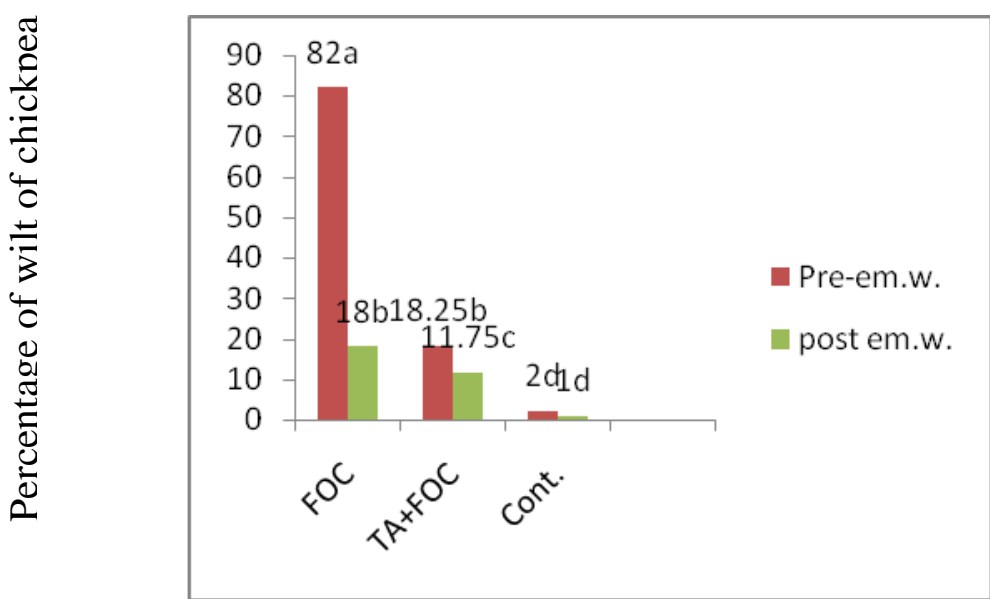

Note: Mean values followed by a different letter indicated significant different $(P=0.05)$, according to Duncan's multiple range test. $(\mathrm{TA}=$ Trichoderma asperellum; $\mathrm{FOC}=$ Fusarium oxysporum ciceri ; Cont.=Control)

Fig.3 Biocontrol of wilt of chickpea by T. asperellum in mini plot trial

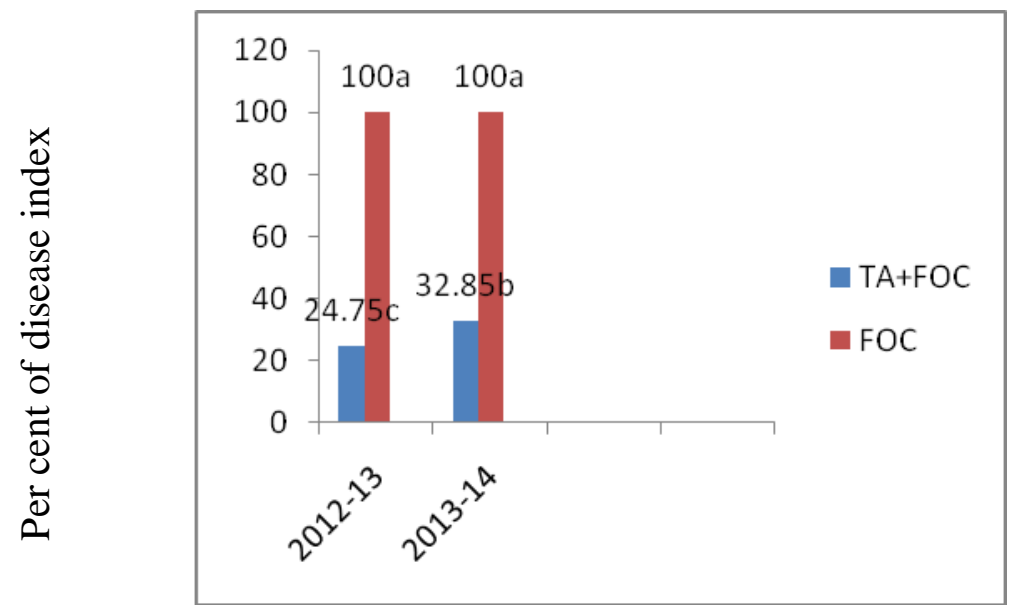

Note: Mean values followed by a different letter indicated significant different $(P=0.05)$, according to Duncan's multiple range test. ( $\mathrm{TA}=$ Trichoderma asperellum; $\mathrm{FOC}=$ Fusarium oxysporum ciceri. )

The growth promotion by Trichoderma may be due to production of secondary metabolites which may act as auxin like compounds (Vinale et al., 2009). Secondary metabolite such as harzianolide, antraquinoues, T39 butinolide isolated from Trichoderma were responsible for increase growth of wheat (Vinale et al., 2008) while harzianic acid increased the growth of canola (Vinale et al., 2009). Altomare et al. (1999) recorded that $T$. harzianum could improve nitrogen use efficacy and could solubilize a number of poorly nutrients such as $\mathrm{Mn}^{4+}, \mathrm{Fe}^{3+}$ and $\mathrm{Cu}^{2+}$,etc enhancing more plant growth and development. The capacity of phosphate solubilization by Trichoderma sp and iron chelating siderophores production are other factors for plant growth promotion (Altomare et al., 1999; Benitez et al., 2004).

\section{Conclusion}

In conclusion, Trichoderma sp have capacity of growth promotion and crop protection from Fusarium wilt disease in agifields. This study revealed that $75.25 \%$ and $67.15 \%$ crop protection respectively in two consecutive years were achieved by applying T. asperellum in seed treatment. Mini plot field trials showed that in both year T. asperellum treated plots gave higher number of pods per plant $(47.25 ; 44.50)$ than control, F.oxysporum ciceri treated, and F.oxysporum ciceri $+T$. asperellum treated 
plots (8.25 \& 12.25$)$. Similarly pulse yields and plant dry weight $(25.9 \& 30.12)$ were higher in compare with control, and than both F.oxysporum ciceri and F.o.c. + T. asperellum treated plots.

It revealed that $T$. asperellum treated plants yielded maximum functional nodules for $\mathrm{N}$-nitrogen fixation and increases root branches allowing roots for more nutrient uptake. Other mechanism for growth promotion by our treated $T$. asperellum may be P-solubilization, siderophore production and other secondary metabolite production as reported by other workers. The efficacy of Trichoderma as BCA is believed to involve antibiotic production and secretion of hydrolytic enzymes and mycoparasitism. Our selected dose of spores $\left(10^{8}\right.$ spores $\left./ \mathrm{ml}\right)$ yields maximum seed germination of Chickpea and this dose of T. asperellum by seed dressing technique gave appreciable crop protection and crop growth promotion. The present finding may suggest that application of Trichoderma asperellum in crop field may reduce or alternative to the application of chemical fertilizer and chemical fungicides to clean environment.

\section{Acknowledgement}

Authors are grateful to the Principal of RKMVC College for providing lab facilities.

\section{References}

Abdalla, M.H., Gutierrez-Mohamed, M.L., Farah, I.O. 2003. Association of pesticide exposure and risk of breast cancer mortality in Mississippi. Biomed. Sci. Instrum., 39: 397-401.

Abdul-Baki, A., Anderson, J.D. 1973. Vigour determination of soybean seed by multiple criteria. Crop Sci., 3, 630-633.

Alabouvette, C., Couteadier, Y. 1992. Biological Control of Plant Diseases: Progress and Challenges for the Future. In: Biological Control of Plant Diseases, Tjamos, E.C., G.C. Papavizas and R.J. Cook. Eds. Plenum Press, New York pp:415-426.

Altomare, C., Norvell, W.A., Bjorkman, T., Harman, G.B. 1999. Solubilization of phosphates and micronutrients by the plant growth-promoting and biocontrol fungus Trichoderma harzianum Rifai 1295-22. Appl. Environ. Microbiol., 65: 2926-2933.

Amarender, R., Devraj, M. 2010. Growth and instability in chickpea production in India. www.krisat.org.

Andrabi, M., Vaid, A., Razdan, V.K. 2011. Evaluation of different measures to control wilt causing pathogens in

chickpea. J plant protection res., 51(1).

Barakat, R.M., Al-Majareeq, F., Al-Masri, M.I. 2006. Biological control of Sclerotium rolfsii by using indigenous Trichoderma spp. Isolates from Palestine. Hebron University, Res. J., 2: 27-47.

Bello, D.K., Wells, H.D., Morkhan, C.R. 1997. In vitroantagonism of Trichoderma species against six fungal plant pathogens. Phytopathol., 72: 579.

Bendre, N.J., Barhate, B.G. 1998. A souvenir on Disease Management in Chickpea, M. P. K. V., Rahuri during $10^{\text {th }}$ Dec. 1998.

Benitez, T., Delgado-Jarana, J., Rincon, A.M., Rey, M., Limon, M.C. 1998. Biofungicides: Trichoderma as a Biocontrol Agent Against Phytopathogenic Fungi. In: Recent Research Developments in Microbiology, Pandalai, S.G.. Ed.. Vol. 2. Research Signpost, Trivandrum, pp: 129-150.

Chang, Y.C., Chang, Y.C., Baker, R., Kleifeld, .O, Chet, I. 1986. Increased growthof plants in the presence of the biological control agent Trichoderma harzianum. Plant Dis., 70: 145-148.

Chen, Y.P., Rekha, P.D., Arunshen, A.B., Lai, W.A., Young, C.C. 2006. Phosphate solubilizing bacteria from subtropical soil and their tricalcium phosphate solubilizing abilities. Appl. Soil Ecol., 34: 33-41.

Chet, I., Brotman, Y., Viterbo, A. 2009. Trichodermaan environment-friendly biocontrol agent of plant disease. Proceedings of the $5^{\text {th }}$ International conference on Biopesticides: Stakeholders perspectives. New Delhi.

Chet, I., Inbar, J., Hadar, Y. 1997. Fungal Antagonists and Mycoparasites. In: The Mycota, Environmental and Microbial Relationships, Wicklow, D.T. and B. Soderstrom (Eds.. Vol. 4, Springer-Verlag, Berlin, Germany, pp: 165-184.

Chutima, R., Dell, B., Vessabutr, S., Busaban, B., Lumyong, S. 2010. Endophytic fungi from Pectielis susannae. L.) Rafin.. Orchidaceae), a threatened terrestrial orchid in Thailand. Mycorrhiza, 21(3): 221-229.

Claydown, K.L., Emerson, O.H., Sauthwell, R.J. 1987. The isolation of a toxic substance from the culture filtrate of Trichoderma. Phytopathol., 36:1068.

Dhingra, O.D., Sinclair, J.B. 1986. Basic plant pathology Methods CRC Press, Inc.

Domsch, K.H., Gams, W., Anderso, T.H. 1980. Compendium of soil Fungi Vol.I \& II, Academic Press London. 
Dubey, S.C., Suresh, M.S. 2007. Evaluation of Trichoderma species against Fusarium oxysporum $f$. $s p$. Ciceris for integrated management of chickpea wilt. Biological Control, 40:118-127.

Eckert, J.W., Ogawa, J.M. 1988. The chemical con trol of postharvest diseases: Deciduous fruits, berries, vegetables and root/tuber crops. Ann. Rev. Phytopathol., 26: 433-446.

Eziashi, E.I., Omamor, I.B., Odigie, E.E. 2007. Antagonism of T.virideand effects of extracted water soluble compounds from Trichoderma spp. and benlate solution on Ceratocystis paradoxa. Afr. J. Biotechnol., 6: 388-392.

FAO. 2012. FAOSTAT Database Results. http://apps.fao/ faostat.

Ghosh, S.k., Ray, S.K., Hasan, M.A. 2014. In Vitro Study of Antagonistic Potential of Some Fungi and Bacteria against Fusarium moniliforme Var. subglutinans, Causal organism of Mango panicle malformation. Acta Horticulturae, 1024: 287-294.

Goetz, A.K., Ren, H., Schmid, J.E., Blystone, C.R., Thillainadarajah, I., Best, D.S., Nichols, H.P., Strader, L.F., Wolf, D.C., Narotsky, M.G., Rockett JC, Dix,DJ. 2007. Disruption of Testosterone

Homeostasis as a Mode of Action for the Reproductive Toxicity of Triazole Fungicides in the Male Rat. Toxological sci., 95(1):227-239.

Grades, M., Bruns, T.D. 1993. ITS primers with enhanced specificity of basidiomycetes: application to the identification of mycorrhizae and rusts. Mol. Ecol., 2: 113-118.

Gupta, S.B., Thakur, M.P., Tedia, K., Singh, A., Bachkaiya, K.K., Kapil, S. 2003. Studies on local isolates of $T$. viride and their relationship with wilt/root rot causing fungi of chickpea (Cicer arietinum L.. p. 182-188. In: "Chickpea Res. for Mellenium”. Proc. Int. Chickpea Conf. Raipur, Chhattisgarh, India, 449 pp.

Harman, G.E. 2006. Overview of mechanisms and uses of Trichoderma spp. Phytopathol., 96: 190-194.

Harman, G.E., Howell, C.R., Viterbo, A., Chet, I., Lorito, M. 2004. Trichoderma speciesopportunistic, avirulent plant symbionts. Nat. Rev. Microbiol,. 2: 43-56.

Harman, G.E., Kubicek, C.P. 1998. Trichoderma and Gliocladium, Enzymes, Biological Control and Commercial Applications, Vol. 2. Taylor \& Francis, London, pp. 393.

Hiltner, L. 1904. Über neuere Erfahrungen und Probleme auf dem Gebiete der Bodenbakteriologie unter besonderer Berücksichtigung der Gründüngung und Brache. Arbeiten der Deutschen Landwirtschaftlichen Gesellschaft 98:59-78.

Holmes, G.J., Eckert, J.W. 1995. Relative fitness of imazalil-resistant and -sensitive biotypes of Penicillium digitatum. Plant Dis., 79:1068-1073.

Howell, C.R. 2003. Mechanisms employed by Trichoderma species in the biological control of plant diseases: the history and evolution of current concepts. Plant Dis., 87: 4-10.

Inbar, J., Abramsky, M., Cohen, D., Chet, I. 1994. Plant growth enhancement and disease control by Trichoderma harzianum in vegetable seedlings grown under commercial conditions. Eur. J. Plant Pathol., 100:337-346.

Jalali, B.L., Chand, H. 1992. Chickpea wilt. In: Plant Diseases of International Importance

(U.S.Singh., A.N. Mukhopadhyay., J. Kumar and H.S.Chaube, ed.),1.Prentice Hall, Englewood Cliffs, NJ, USA 429-444.

Kanetis, L., Forster, H., Adaskaveg, J.E. 2008. Baseline sensitivities for new postharvest fungicides against Penicillium spp. on citrus and multiple resistance evaluations in $P$. digitatum. Plant Dis., 92: 301-310.

Karthikeyan, V., Sankaralingam, A., Nakkeeran, S. 2006. Biological Control of groundnut stem rot caused by Sclerotium rolfsii. Sacc. Arch. Phytopathol Plant Protection, 39: 239-246.

Keel, C., Schnider, U., Maurhofer, M., Voisand, C., Laville, J., Burger, U., Wirthner, P., Han, D., Defago, G. 1992. Suppression of root disease by Pseudomonas flurescens strain $\mathrm{CHAO}$ impotance of the bacterial secondary metabolites.

Khan, R.M., Khan, S.M., Fayaz, A.M. 2004. Biological control of Fusarium wilt of chickpea through seed treatment with the commercial formulation of Trichoderma harzianum and / or Pseudomonas fluorescens. Phytopathol. Mediterr., 43: $20-25$.

Kimura, Y., Mizuno, T., Hamasaki, T., Altochromones, A.B. 1992. New Plant growth regulators produced by fungus Alternaria sp. Biosci. Biotechnol. Biochem., 56: $1064 \quad-1065$.

Kleifeld, O., Chet, I. 1992. Trichoderma harzianuminteraction with plants and effect on growth response. Plant Soil, 144: 267-272.

Krishnamurthy, A.S. 1987. Biological control of damping off disease of tomato caused by Phythium indicum Balkrishnan M.Sc.(Ag) thesis, Tamil Nadu Agricultural University Coimbatore, pp.98. 
Kumar, D., Dubey, S.C. 2001. Management of collar rots of pea by the integration of biological and chemical methods. Indian Phytopath., 57: 62-66.

Larito, P., Webster, J., Lomas, N. 1976. Trichoderma viride produce gliotoxin and viridin. Transactions of British Mycological Society, 47:535.

Lee, W.J., Sandler, D.P., Blair, A., Samanic, C., Cross, A.J., Alavanja, M.C. 2007. Pesticide use and colorectal cancer risk in the agricultural health study. Int J. Cancer, 121(2): 339-46.

Lynch, J.M., Hobbie, J.E. 1991. Concepts and application in microbial ecology, in microorganisms in action. Block wellScientific publication. 261: 8794.

Mc Cully, M. 2005. The rhizosphere: the key functional unit in plant/soil/microbial interactions in the field. Implications for theunderstanding of allelopathic effects. In Proceedings of the 4th World Congress on Allelopathy: 21-26 August 2005; Charles Sturt University, Wagga Wagga, NSW, Australia. International Allelopathy Society. Edited by Harper J, An M, Wu H, Kent J.

Meinert, R., Schüz, J., Kaletsch, U., Kaatsch, P., Michaelis, J. 2000. Leukemia and non-Hodgkin's lymphoma in childhood and exposure to pesticides: results of a register-based case- control study in Germany. Am. J. Epidemiol., 151(7):63950.

Mukhopadhyay, A.N. 2009. Challenges, Charges and Choices before Trichoderma based biopesticides. Proceedings of $5^{\text {th }}$ International Conference on Biopesticides: Stakeholders Perspectives, New Delhi.

Nene, Y.L., Reddy, M.V. 1987. Chickpea Diseases and their Control. In: Saxena M.C., Singh K. B., The Chickpea. Oxon, UK: CAB International. pp. 233-270.

Ozbay, N., Newman, S.E., Brown, W.M. 2004. The effect of the Trichoderma strains on the growth of tomato seedlings. Acta Hort., 635:131-135.

Pan, S., Ghosh, S.K. 1997. Antagonistic Potential of some soil fungi on Phytopthora colocasiae Racib. J. Mycopathol. Res. 35. 2): 153-157.

PAN. 2007.http:// www.paninternational.org/panit/file/WG1/Eliminating the worst pesticide.pdf

Poddar, R.K., Singh, D., Dubey, S.C. 2004. Integrated application of Trichoderma harzianum mutants and carbendazim to manage chickpea wilt. Fusarium oxysporum f.sp. ciceris. Indian J. Agric. Sci, $74:$ 346- 348.
Ponmurugan, P., Baby, U.I. 2003. In vitro interaction of fungal antagonists with Phomopsis theae, the causal agent of collar canker disease in tea. Indian $J$. Microbiol., 43, 41-44.

Powler, D. 2006. "Blue baby links - 11 February 2006 New Scientist". Retrieved 2008-03- 24.

Primavesi, A., PrimavesI, A.M. 1990. Soil life and chemical fertilizers ILEIA Newsletter $\quad \cdot 6 n^{\circ} 3$ • October 1990(www.agriculturenet.org)

Rai, B., Singh, T.S. 2004. Influence of plant growth promoting fungi on growth and yield of chickpea, pea and mustard. J. Mycopathol. Res., 42(1): 9-13.

Rockett, J.C., Narotsky, M.G., Thompson, K.E., Thillainadarajah, I., Blystone, C.R., Goetz, A.K., Ren, H., Best, D.S., Murrell, R.N., Nichols, H.P., et al.. 2006. Effects of conazole fungicides on reproductive development in the female rat. Reprod Toxicol., 22:647-658.

Schafer, K.S., Reeves, M., Spitzer, S., Kegley, S.E. 2004. Chemical Trespass, Pesticides in Our Bodies and Corporate Accountability, Pesticide Action Network North America.

Sharma, A.K. 2003. Biological Mobilization of Phosphorous In: Biofertilizers for Sustainable Agriculture. Agrobios, Jodhpur, India. 194 - 232.

Sivasithamparam, K., Ghisalberti, E.L. 1998. Secondary metabolism in Trichoderma and Gliocladium. In:Basic Biology, Taxonomy, and Genetics, Vol. 1,. C.P. Kubicek, G.E. Harman, ed.), Taylor \& Francis, Inc., London, UK, pp. 287

Smilanick, J.L. 2011. Integrated Approaches to Postharvest Disease Management in California Citrus Packinghouses in: Proc. IS on Biological Control of Postharvest Diseases Eds.: M. Wisniewski and S. Droby Acta Hort. 905, ISHS pp145-148.

Smith, P., Martino, D., Cai, Z., Gwary, D., Janzen, H., Kumar, P., Mc-Carl, B., Ogle, S., O’Mara, F., Rice, C., Scholes, .B, Sirotenko, O., Howden, M., McAllister, T., Pan, G., Romanenkov, V., Schbeider U, Towprayoon S, Wattenbach M, Smith J. 2008. Greenhouse gas mitigationin agriculture. Philosophical Transaction of the Royal Society, 363:789- 813.

Sonawane, S.S., Pawar, N.B. 2001. Studies on biological management of chickpea wilt. Maharashtra Agric. Univ., 26: 215-216.

Souchie, E.L., Azcón, R., Barea, J.M., Saggin-Júnior, O.J., da Silva, E.M.R. 2007. Indolacetic acid production by P-solubilizing microorganisms and interaction with arbuscular mycorrhizal fungi. Acta Scientiarum-Biological Sci., 29(3): 315-320 
Spotts, R.A., Cervantes, L.A. 1986. Populations, pathogenicity and benomyl resistance of Botrytis spp, and Mucor piriformis in packinghouse test. Plant Dis., 70:106-108.

Srivastava, V.K. 2004. Trichoderma spp- a boon for better crop health. Pest. XXVIII 8:40.45.

Tewari, A.K., Mukhopadhyay, A.N. 2001. Testing of different formulations of Trichoderma virens against chickpea wilt complex. Indian Phytopathol., 54: 37-71.

Tronsmo, A., Harman, N. 1992. Effect of temperature on antagonistic properties of Trichoderma species.Transactions of British Mycological Society, 71:469.

US Dept of Health and Human Services. 2008. actor.epa.gov/actor/generic chemical.

Vinale, F., Flemati, G., Sivasithamparam, K., Lorito, M, Marra R, Skelton, B.W., Ghisalberti, E.L. 2009. Harzianic acid, an antifungal and plant growth promoting metabolite from Trichoderma arzianum. J. Nat. Prod.,72: 2032-2035.

Vinale, F., Ghisalberti, E.L., Sivasithamparam, K., Marra R., Ritieni, A., Ferracane, R., Woo, S.L., Lorito M. 2009. Factors affecting the production of Trichoderma harzianum secondary metabolites during the interaction with plant pathogens. Lett. Appl. Microbiol., 48:705-711.

Vinale, F., Sivasithamparam, K., Ghisalberti, E.L., Marra R., Barbetti, .M.J, Li, H., Woo, S.L., Lorito, M. 2008. A novel role for Trichoderma secondary metabolites in the interactions with plants. Physiol. Mol. Plant Pathol., 72: 80-86.

Vinale, F., Sivasithamparam, K., Ghisalberti, E.L., Marra, R., Woo, S.L., Lorito, M. 2008. Trichoderma-plant-pathogen interactions. Soil Biol Biochem., 40:1-10.

Ward, M.H., De-Kok, T.M., Levallois, P., Brender, J., Gulis, G., Nolan, B.T., Van-Derslice, J. 2005. "Workgroup Report: Drinking-Water Nitrate and Health-Recent Findings and Research

Needs". Environ. Health Perspectives, 113(11): 1607-1614.

Wei, G., Kloepper, J.W., Sadik, T. 1991. Induction of systemic resistance of cucumber to Colletotrichum orbiculare by select strains of plant growth promoting rhizobacteria, Phytopathol., 1:15081512.

White, T.J., Bruns, T., Lee, S., Tylor, J.W. 1990. Amplification and direct sequencing of fungal ribosomal RNA genes for phylogenetics, PCR protocols: a guide to method and applications, Academic, New York p.315-322.

Windham, M.T., Elad, Y., Baker, R. 1986. A mechanical for increased plant growth induced by Trichoderma sp. Phytopathol., 76: $518-521$.

Zaidi, A., Khan, M.S., Ahemad, M., Oves, M. 2009. Plant growth promotion by phosphate solubilizing bacteria, Acta Microbiol. Immunol. Hung., 56 : 263284.

\section{How to cite this article:}

Swapan Kumar Ghosh and Sujoy Pal. 2017. Growth Promotion and Fusarium Wilt Disease Management Ecofriendly in Chickpea by Trichoderma asperellum . Int.J.Curr.Res.Aca.Rev. 5(1), 14-26.

doi: http://dx.doi.org/10.20546/ijcrar.2017.501.002 